\title{
PEMANFAATAN APLIKASI WHATSAPP PADA PEMBELAJARAN BAHASA INDONESIA DI SMK TUNAS BANGSA TAWANGSARI DENGAN METODE DARING
}

\section{UTILIZATION OF THE WHATSAPP APPLICATION IN INDONESIAN LANGUAGE LEARNING AT SMK TUNAS BANGSA TAWANGSARI WITH THE ONLINE METHOD}

\author{
Dafit Exfarudin ${ }^{1}$, Putri Ramadhaningrum ${ }^{2}$, Suparmin $^{3}$, Sarwini $^{4}$ \\ Program Studi Pendidikan Bahasa dan Sastra Indonesia \\ Universitas Veteran Bangun Nusantara Sukoharjo ${ }^{1,2,3}$ \\ SMK Tunas Bangsa Tawangsari \\ Pos-el: exfardhe3107@gmail.com¹, ramadaningrumputrianantha@gmail.com², \\ spmsup7@gmail.com ${ }^{3}$,smktb.sarwini@gmail.com ${ }^{4}$
}

*)Naskah diterima: 12 Desember 2020; direvisi: 12 Desember 2020; disetujui: 10 Juni 2021

\begin{abstract}
Abstrak
Penelitian ini bertujuan untuk mengetahui pemanfaatan WhatsApp pada pembelajaran bahasa Indonesia di SMK Tunas Bangsa Tawangsari dengan metode daring. Kegiatan mengajar biasanya dilakukan secara tatap muka, tetapi setelah terjadi pandemi ini, Sekolah Menengah Kejuruan Tunas Bangsa Tawangsari melaksanakan Pembelajaran Jarak Jauh (PJJ) dengan menggunakan aplikasi WhatsApp. Dalam artikel, ini penulis menggunakan strategi subjektif yang berbeda. Dengan memanfaatkan strategi grafis subjektif dalam eksplorasi ini, objek objektif fundamental yang digunakan dalam penelitian ini adalah siswa kelas XI SMK Tunas Bangsa Tawangsari. Metode yang digunakan dalam penelitian ini adalah metode deskriptif kualitatif untuk mengetahui pemanfaatan aplikasi WhatsApp dalam pembelajaran daring di masa pandemi. Manfaat yang ditemukan dalam pembelajaran menggunakan aplikasi WhatsApp ini adalah guru dan siswa dapat bertanya serta menanggapi segala pertanyaan dengan lebih mudah, guru juga bisa memantau siapa saja yang sudah membuka dan membaca pembelajaran yang sudah $d i$-share, guru juga dapat mengirimkan materi pembelajaran berupa audio untuk penjelasan materi serta dokumen untuk materi tulis pada grup WhatsApp, guru dan siswa bisa mengulangi pembelajaran atau materi yang sudah di kirimkan melalui grup kapan saja dan juga lebih mudah. Bisa dikatakan pembelajaran Jarak Jauh (PJJ) di SMK Tunas Bangsa Tawangsari dengan menggunakan aplikasi WhatsApp pada masa pandemi ini sangat efektif dan efisien untuk pembelajaran secara daring. Seorang guru dapat menyampaikan materi melalui berbagai fitur yang disediakan oleh WhatsApp dengan berbagai fungsi dalam satu aplikasi.
\end{abstract}

Kata kunci: aplikasi, pembelajaran daring, WhatsApp

\begin{abstract}
This study aims to determine the use of WhatsApp in Indonesian language learning at SMK Tunas Bangsa Tawangsari using the online method. Teaching activities are usually carried out face-to-face, but after this pandemic, the learning process of the Tunas Bangsa Tawangsari Vocational High School which was originally offline or outside the network has changed to online or online. The problem in the
\end{abstract}


world of education during the pandemic is how to keep students studying even at home. In this case, SMK Tunas Bangsa Tawangsari implements Distance Learning (PJJ) using the WhatsApp application. In this article the author uses a different subjective strategy. By utilizing the subjective graphic strategy in this exploration, the fundamental objective object used in this research is the XI grade students of SMK Tunas Bangsa Tawangsari. The method used in this study is a qualitative descriptive method to determine the use of the WhatsApp application in online learning during the pandemic. The benefits found in learning using the WhatsApp application are that teachers and students can ask and respond to all questions more easily, the teacher can also monitor who has opened and read the lessons that have been shared, the teacher can also send learning material in the form of audio for explanation materials and documents for written material in the WhatsApp group, teachers and students can repeat learning or material that has been sent through the group at any time and this is easier too. It could be said that distance learning (PJJ) at SMK Tunas Bangsa Tawangsari using the WhatsApp application during the pandemic was very effective and efficient for online learning. A teacher can deliver material through various features provided by WhatsApp with various functions in one application.

Keywords: applications, online learning, WhatsApp

\section{PENDAHULUAN}

Kemunculan perdana pandemi korona bermula di Wuhan pada dunia pendidikan akhir tahun 2019 yang akhirnya menyebar keseluruh dunia. Hal ini menjadikan sebuah tantangan dalam dunia pendidikaan sekarang, terlebih lagi yang sedang menempuh pendidikan di seluruh lembaga pendidikan formal serta informal. Untuk mengurangi penyebarannya, pemberitahuan sudah mengumumkan kepada semua sekolah untuk mengharuskan menyudahi belajar langsung di kelas serta mengirim materi pengajaran di rumah lewat pengajaran online menggunakan komunikasi online hingga keadaan memungkinan untuk kembali melakukan pembelajaran secara tatap muka di sekolah (P, Acero, K. Cabas, C. Caycedo, P. Figueroa and Aceh, 2020). Maraknya wabah Covid-19 tersebut mengharuskan bermacam pihak mengulas kembali perspektif pembelajaran lebih-lebih yang terserang akibat atas kondisi tersebut. Pembelajaran yang sebelumnya berjalan secara langsung, saat ini berubah menjadi daring.

Terdapatnya endemi ini menyerang semua negara internasional, tidak luput pula Indonesia. Bersumber pemberitahuan terkini oleh Lembaga Kesehatan Global (World Health Organization), sejumlah 213 bangsa sudah terkena Covid-19, lebih dari dua setengah juta penduduk terdata terjangkit serta lebih dari seratus delapan puluh ribu jiwa tewas. Pandemi tersebut tergolong dapat berinfeksi, primer maupun sekunder antarindividu. Situasi tersebut bisa memengaruhi sistem respirasi semacam hidung, kerongkongan, serta paru-paru. Kerumitan penindakan pandemi ini, minimnya vaksin dan obat-obatan yang bisa dipakai guna menjaga penderita terhadap virus ini, serta minimnya pemakaian alat penjaga diri (APD) bagi paramedis membuat negara mempraktikkan kebijaksanaan yang jelas guna memutuskan penjangkitan virus ini. Untuk memutus penjangkitannya dilakukan dengan mengurangi kontak antarindividu (Mustakim, 2020).

Undang-Undang Nomor 20 Tahun 2003 mengenai Sistem Pendidikan Nasional menekankan pembelajaran ialah suatu langkah komunikasi antara siswa dan guru, serta antara sarana pembelajaran dalam sebuah metode pembelajaran untuk 
memperoleh ilmu pengetahuan (Arifin, 2020).

Belajar secara virtual merupakan bentuk interaksi yang menghubungkan peserta didik serta pengajarnya untuk saling berinteraksi secara daring (Kuntarto, 2017). Pemakaian teknologi pada pembelajaran ialah cara lain memperbaiki mutu langkah serta capaian akhir dalam pembelajaran. Oleh karena itu, kepala sekolah mewajibkan pengajar serta siswa secara rutin memakai teknologi pada langkah pengajaran.

Proses pembelajaran secara virtual atau pembelajaran secara daring ialah proses pengajaran yang dilaksanakan non primer, dengan tetapi lewat basis yang sudah ada. Seluruh wujud modul pelajaran didistribusikan dengan cara online, serta uji dijalankan dengan cara virtual. Proses pengajaran online didukung oleh berbagai metode, semacam Google Classroom, Google Meet, Edmodo, Zoom, dan WhatsApp. Pengajaran daring dalam intinya merupakan pengajaran berbentuk metode berbicara dengan cara askiron, yang artinya bentuk komunikasinya sekunder. Asinkron yaitu bila pengirim mengantarkan perintah pukul 7.00, hingga pemeroleh perintah amat memungkin menyambut perintah di kala tersebut. Namun, para pendidik yang tidak mengetahui bentuk asikron yang terjalin dalam di kala cara pengajaran.

Dewasa ini, sudah bertumbuh aneka metode pengajaran lewat virtual dengan menggunakan berbagai media sebagai penunjang pembelajaranjarak jauh. Dengan begitu, sekolah perlu menyiapkan metode penunjang pengajaran tanpa terbatas ruang supaya pendidikan tetap berjalan walaupun sistemnya berbeda. Saat ini, sudah banyak teknologi yang dapat menunjang sistem pembelajaran, salah satunya dengan menggunakan WhatsApp. Salah satu sekolah yang menggunakan media tersebut adalah SMK Tunas Bangsa Tawangsari.
Artikel ini akan membahas media yang digunakan di SMK Tunas Bangsa Tawangsari yaitu WhatsApp. Adapun rumusan masalahnya yaitu, bagaimana pemanfaatan aplikasi WhatsApp dalam pembelajaran daring?

\section{LANDASAN TEORI}

\section{Pembelajaran Daring}

Menurut Kuntaro, E. (2017) Pembelajaran daring merupakan bentuk interaksi pengajar dengan siswa bertujuan melakukan kontak pengajaran menggunakan data virtual (Sadikin and Hamidah 2020) dan menurut Munir (2012: 16) pembelajaran jarak jauh atau daring mengacu pada situasi dimana metode pengajaran secara sekunder antara guru dan siswa. Komunikasi relasi yang dihubungkan melalui perantara semacam perantara cetak serta perantara non cetak. Pembelajaran jarak jauh atau daring ialah metode telah terkonsep pada ruang lainnya.

\section{WhatsApp}

WhatsApp adalah media seluler berplatform jaringan contoh hasil pertumbuhan kecanggihan data terpopuler karena WhatsApp banyak digunakan di kalangan masyarakat dan penggunaan WhatsApp tergolong mudah, serta WhatsApp tak berbayar, tetapi menggunakan koneksi jaringan seluler (Pranajaya \& Hendra Wicaksono, 2017). Bagi Larasati, dkk. (2013) (dalam (Rahartri 2019), WhatsApp bentuk media untuk bertukar pesan, catatan, catatan bersuara serta bisa dipakai pula bertukar informasi serta bertukar pikiran. Larasati meringkaskan kategori yang benar meliputi penggunaan WhatsApp sebagai metode pengajaran serta berbagi ilmu.

\section{Pembelajaran Bahasa Indonesia}

Pembelajaran bahasa Indonesia merupakan salah satu pembelajaran yang wajib 
dilaksanakan pada pendidikan di Indonesia. Pembelajaran bahasa Indonesia memiliki empat keterampilan berbahasa yang harus dimiliki siswa yaitu keterampilan mendengarkan, berbicara, membaca, dan menulis (Dalman, 2012).

\section{METODE PENELITIAN}

Penggunaan metode merupakan faktor penentu berhasilnya suatu riset sebab metode pemahaman terhadap poin penelitian. Penelitian ini dibuat berdasarkan pengalaman lapangan di SMK Tunas Bangsa Tawangsari yang menerapkan aplikasi WhatsApp dalam pembelajaran daring. Metode penelitian kualitatif deskriptif dipakai untuk riset ini. Metode kualitatif merupakan penelitian kualitatif yang capaiannya sukar didapat melalui kuantitatifikasi lainnya (Sartika, 2018). Pada riset tersebut memakai prosedur deskriptif yang bermaksud guna membagikan cerminan tentang pemanfaatan aplikasi WhatsApp dalam pembelajaran daring di SMK Tunas Bangsa Tawangsari. Teknik pengumpulan data dilakukan dengan pengumpulan berupa informasi dan gambar, data yang telah diperoleh tersebut kemudian dijabarkan secara deskriptif.

\section{HASIL DAN PEMBAHASAN}

Ada beberapa media sosial yang dapat digunakan sebagai alat komunikasi antara lain Facebook, Twitter, Line, Messenger, WhatsApp. Namun, bentuk jejaring sosial yang kerap dimanfaatkan bagi banyak individu di seluruh dunia dalam proses komunikasi yaitu WhatsApp. WhatsApp dibuat oleh pasangan eks pegawai Yahoo serta mempunyai keahlian, yakni Brian Acton dan Jan Koum. Inspiransinya dari dua arti frasa bahasa inggris bermakna sapaan. Tujuan mereka menciptakannya supaya ada pengganti lainnya yang kian efektif daripada pesan singkat. Brian Action dan Jan Koum menciptakan WhatsApp Inc di saat gencarnya Lembah Silikon saat Februari 2009 dan diakuisisi sejumlah US\$19 Milyar saat Februari tahun 2014 oleh Facebook, ialah industri yang sempat menyangkal lamarannya Brian Action. Indikator pengguna WhatsApp terbagi menjadi 6 antara lain Group Whatsapp untuk reuni, Group WhatsApp untuk diskusi, mengirim undangan acara, menelpon, berbagi lokasi, WhatsApp Web (Mustika, 2020).

Jumiatmoko (2016) (dalam Rahartri, 2019) mengatakan bahwa WhatsApp merupakan aplikasi website membolehkan tiap pemakai menyediakan materi yang berlainan terkait dalam kelebihan yang mereka bawa. WhatsApp pula mempunyai bermacam kelebihan yang bisa dipakai berbicara lewat virtual. WhatsApp ialah alat sosial terpopuler serta bisa dipakai sebagai alat berkomunikasi. Umumnya pemakai WhatsApp membagikan penyebabnya memutuskan aplikasi tersebut sebab WhatsApp mempunyai banyak sarana. Fitur- fitur yang terdapat ialah galeri untuk mengunggah gambar, kontak untuk memasukkan kontak, kamera untuk pengambilan gambar, suara untuk mengirim catatan bersuara, Maps mengirim lokasi, terakhir Doc untuk mengirim file berupa dokumen.

WhatsApp merupakan media seluler berplatform website yang berintegrasi dengan bermacam media yang dipakai guna berbicara dengan pemakai lainnya, mulai dari pembelajaran, bidang usaha, intermezzo sampai bermacam media yang dibesarkan pada aplikasinya tersebut. Di tengah peningkatannya, aplikasi tersebut dituntut bisa memakai WhatsApp tidak cuma keperluan perpesanan serta chain messaging, dan kegunaan aplikasi kolaboratif serta memberi data, alhasil pencapaian e-learning jadi nyata. (Prajana, 2017).

Secara fungsional, Whats App merupakan media perpesanan praktis seluler. WhatsApp mirip media pesan singkat, tetapi WhatsApp 
tidak memerlukan biaya operator selain koneksi jaringan. Meski merupakan aplikasi perpesanan praktis, WhatsApp tetap memiliki beberapa fitur unik. Oleh karena itu, sistem identifikasi, verifikasi dan notifikasi kontak masih diterapkan melalui nomor ponsel yang terdaftar. WhatsApp memungkinkan semua orang menghasilkan dan berbagi banyak hal, terdapat beberapa fitur di dalam WhatsApp yakni: mengirimkan perpesanan singkat, mengirimkan gambar, mengirimkan gambar bergerak, mengirimkan dokumen, melakukan panggilan bersuara, termasuk mengirimkan pesan bersuara yang bisa diterima kapan pun, mengirimkan letak posisi, mengirim kartu nama. Gambar di bawah ini menunjukan berbagai fitur yang tersedia di dalam chat WhatsApp.

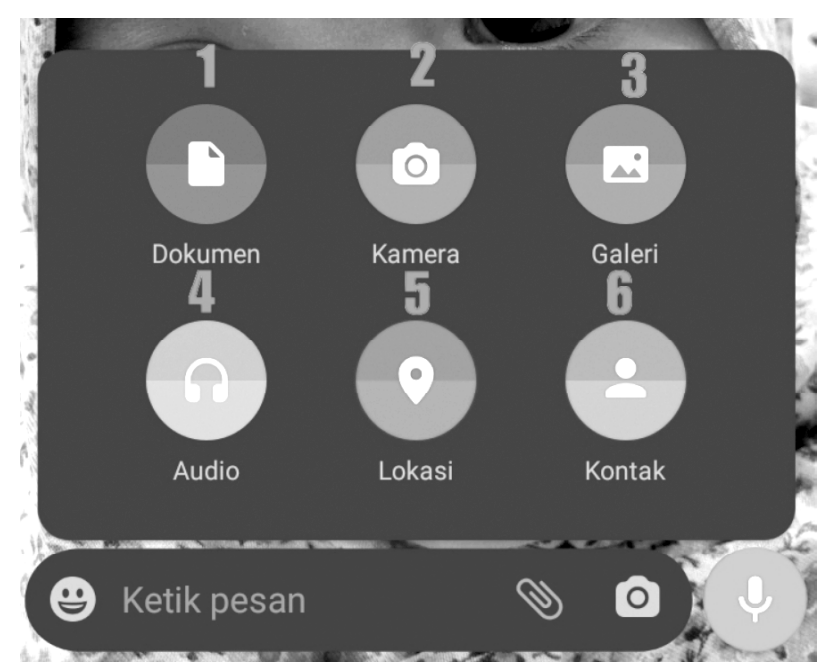

(Gambar 1. fitur aplikasi chat WhatsApp)

Keterangan :

1. Dokumen berguna untuk mengirim file

2. Kamera berguna untuk memotret suatu objek

3. Galeri berguna untuk mengirimkan foto dan video
4. Audio berguna untuk mengirimkan rekaman audio

5. Lokasi berguna untuk berbagi lokasi dengan memanfaatkan GPS

6. Kontak berguna untuk mengirimkan kartu kontak

Dalam fitur chat WhatsApp yang digunakan di SMK Tunas Bangsa Tawangsari satah satu manfaat yang digunakan adalah mengirim pesan, mengirim file/dokumen, mengirim pesan suara.

Dalam proses pembelajaran menggunakan aplikasi WhatsApp, guru dapat melaksanakan pembelajaran dimulai dari mengirimkan audio yang berisikan salam serta memnberikan informasi kepada peserta didik untuk tetap semangat belajar dengan menjalankan protokol kesehatan sering mencuci tangan dan selalu memakai masker, guru. Mengirimkan modul yang bakal dipakai berbentuk Power Point, peserta didik mengunduh file tersebut lalu mencermati materi tersebut, guru mempersilakan anak didik guna menanya berhubungan modul yang diterima, pendidik membagikan tugas pada anak didik dalam bentuk Word yang dikirimkan di group, setelah pembelajaran berakhir guru melakukan presensi dengan mengirimkan list presensi. Gambar di bawah ini merupakan pemanfaatan WhatsApp yang digunakan selama proses pembelajaran berlangsung. 


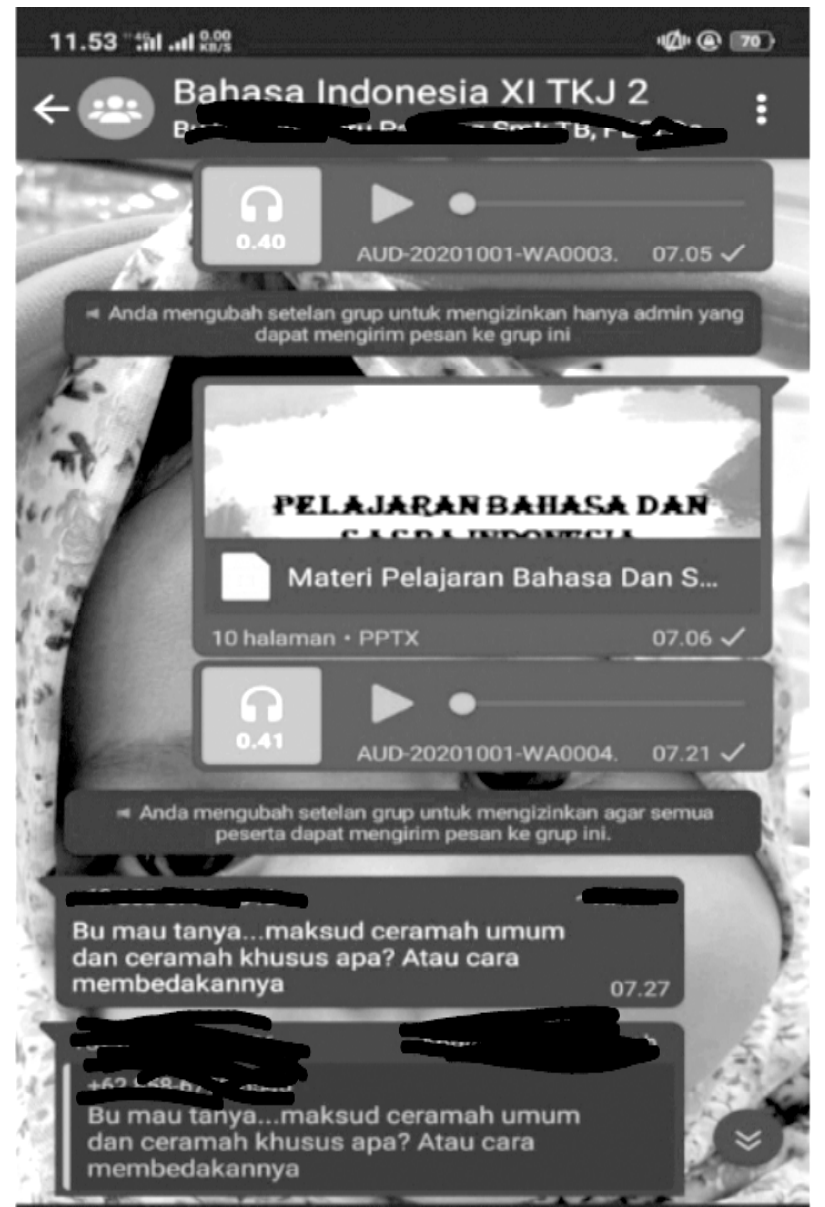

(Gambar 2. Pemberian materi di dalam group WhatsApp)

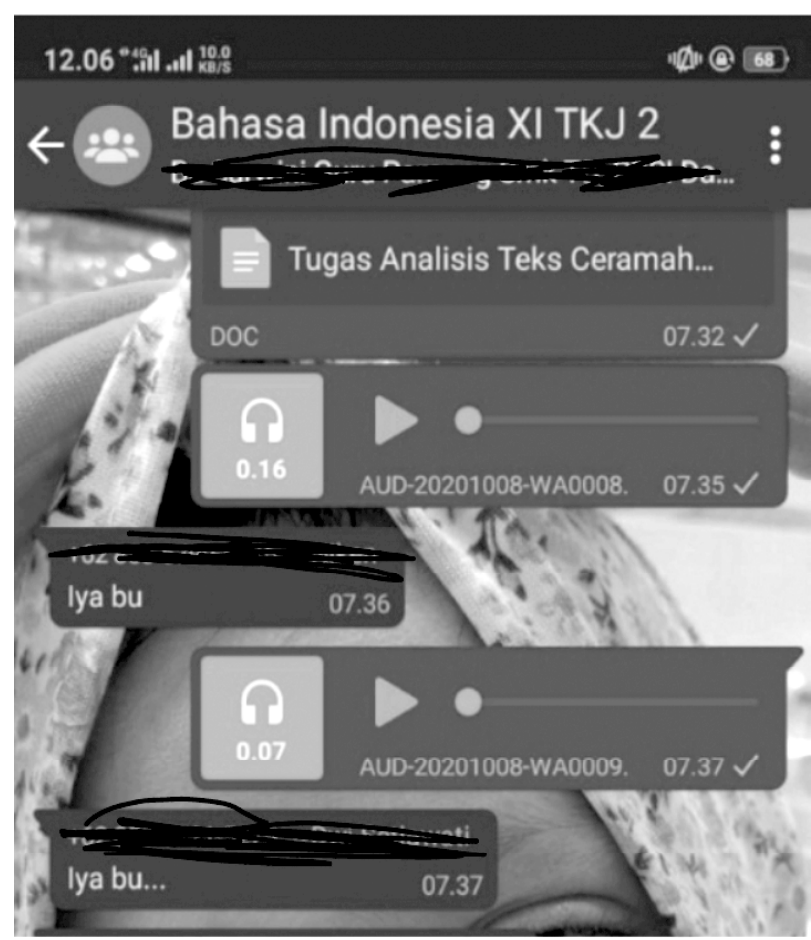

(Gambar 3. Pemberian tugas di dalam group WhatsApp)

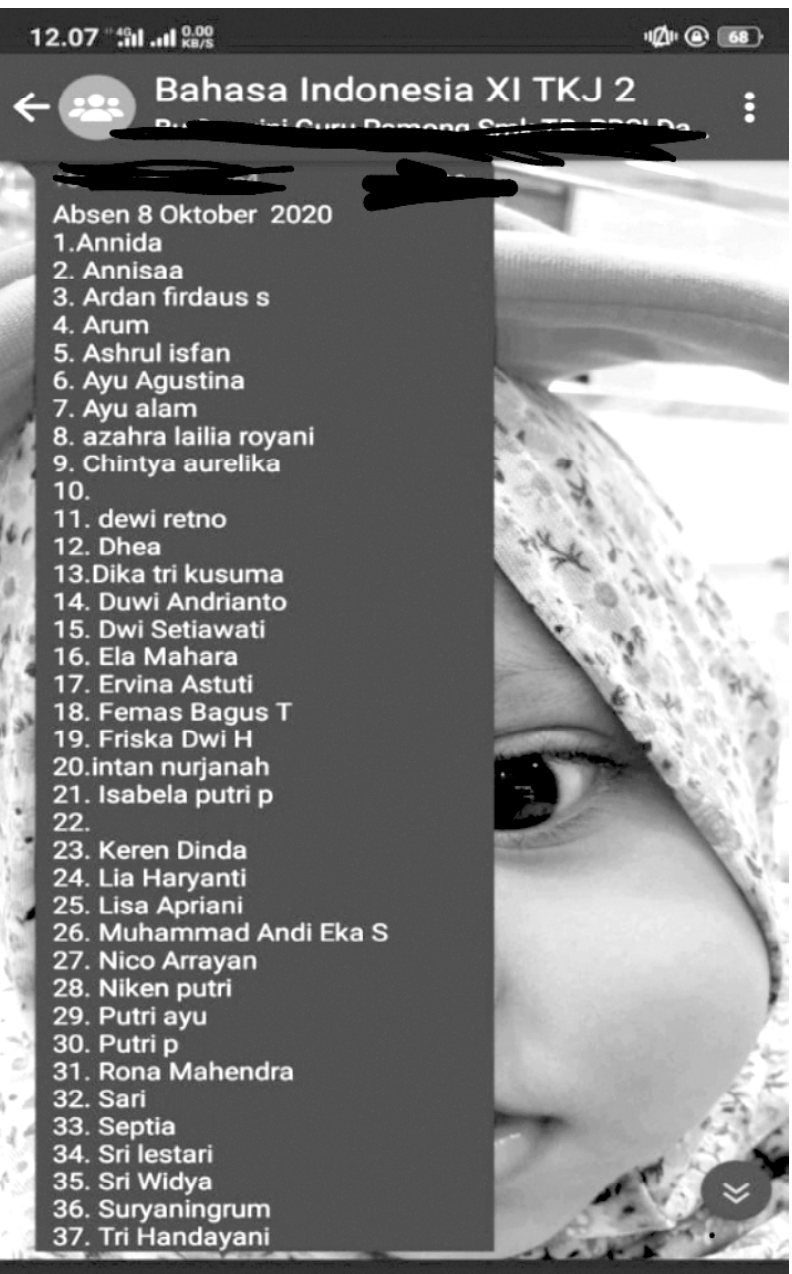

(Gambar 4. Presensi di dalam grup WhatsApp)

Dengan menggunakan aplikasi WhatsApp, pembelajaran dapat berlangsung dengan efisien serta dapat mempermudah pendidik serta anak didik pada saat pengajaran. Tidak hanya tersebut, siswa pun dapat menyampaikan hasil pemikiran masing-masing terhadap pertanyaan yang diberikan oleh guru. WhatsApp juga dapat digunakan untuk video call dalam pembelajaran tatap muka melalui daring. Namun, video call tersebut hanya bisa memuat 8 orang saja.

Dengan menerapkan pembelajaran daring mempunyai beberapa manfaat, antara lain mengajarkan siswa tentang kedisiplinan dan tanggung jawab, sistem belajar siswa lebih dinamis sebab bisa dijalan di manapun serta anak juga tidak harus duduk berjamjam yang biasa dilakukan di dalam kelas, 
dapat melatih kemampuan motorik dan kolaborasi pada siswa.

Keuntungan pembelajaran daring melalui WhatsApp, antara lain sebagai berikut. Tak terbatas apapun, murid dapat dengan leluasa menyelesaikan PR (Pekerjaan Rumah) kapanpun dan di mana pun, serta perlu mengumpulkan catatan dalam waktu yang telah ditentukan, serta data internet yang digunakan dalam aplikasi WhatsApp lebih ringan daripada aplikasi yang lain. Selain $i$ itu, terdapat kendala dalam penggunaan WhatsApp yaitu siswa masih cukup pasif dalam pelaksaan pembelajaran daring, beberapa siswa mengalami kendala seperti sinyal di daerahnya yang kurang mendukung.

\section{PENUTUP}

Dengan menggunakan aplikasi WhatsApp dalam kegiatan pembelajaran daring terdapat beberapa manfaat antara lain guru dan siswa dapat bertanya serta menanggapi segala pertanyaan dengan lebih mudah, guru juga bisa memantau siapa saja yang sudah membuka dan membaca pembelajaran yang sudah di share, guru juga dapat mengirimkan materi pembelajaran berupa audio untuk penjelasan materi serta dokumen untuk materi tulis pada grup Whatsapp, guru dan siswa bisa mengulangi pembelajaran atau materi yang sudah di kirimkan melalui grup kapan saja dan juga lebih mudah.

Dengan bermacam-macam fitur dalam satu aplikasi membuat banyak kemudahan bagi guru dan siswa dalam penggunaannya, karena guru dapat menyampaikan bahan ajar dengan menggunakan berbagai kemudahan atau fitur yang telah disediakan oleh WhatsApp, tidak hanya berupa teks melainkan bisa berupa video, rekaman suara, dan gambar. Selain itu, guru dapat juga memantau keaktifan siswanya dengan fitur chat, serta dapat dengan efisien dalam mem- berikan tugas sebagai bahan evaluasi untuk mengetahui tingkat pemahaman siswa. Selain itu, WhatsApp juga dapat digunakan untuk video call dalam pembelajaran tatap muka melalui daring. Hal ini menunjukkan bahwa pembelajaran menggunakan Whats App cukup efisien dalam proses pembelajaran daring saat ini.

Berdasarkan paparan mengenai hasil penelitian dan simpulan adapun saransaran yang dapat disampaikan peneliti antara lain sebagai berikut.

\section{Bagi Guru Bahasa Indonesia}

Secara umum penggunaan media aplikasi WhatsApp dalam proses pembelajaran daring di SMK Tunas Bangsa Tawangsari sudah baik dan berjalan dengan efektif. Untuk ke depannya, sebaiknya guru tetap mempertahankan hal tersebut agar lebih dapat membantu guru dalam memberi materi serta mengajarkan materi kepada peserta didik.

\section{Bagi Peserta Didik}

Bagi peserta didik, penggunaan media aplikasi WhatsApp dalam proses pembelajaran daring lebih fokus lagi agar saat proses pembelajaran dapat berhasil serta terlaksana dengan baik, dan peserta didik mampu menguasai materi yang telah diberikan oleh guru.

\section{Bagi Sekolah}

Pada daya dukung pembelajaran daring di SMK Tunas Bangsa Tawangsari sudsh baik, untuk ke depannya penulis mengharapkan sekolah dalam pembelajaran daring menggunakan media aplikasi WhatsApp pada pembelajaran bahasa Indonesia untuk dimanfaatkan dengan sebaik-baiknya, sehingga penggunaan media aplikasi WhatsApp dalam proses pembelajaran daring tetap berjalan dengan lancar dan efisien. 


\section{Bagi Penulis Lain}

Dalam penelitian ini diharapkan dapat dijadikan acuan untuk meneliti masalah yang sejenis dan peneliti mengharapkan agar peneliti lain dapat melakukan penelitian lanjutan terhadap pemanfaatan aplikasi WhatsApp pada pembelajaran bahasa Indonesia dengan menggunakan metode daring sehingga didapatkan hasil yang lebih maksimal.

\section{DAFTAR PUSTAKA}

Arifin, Muhammad. 2020. Manajemen Pembelajaran Pendidikan Jarak Jauh Untuk Millenial.Sukabumi: Haura Publishing.

Dalman, 2012. Keterampilan Menulis. Jakarta: Rajawali Pers.

Kuntarto, Eko. 2017. “Keefektifan Model Pembelajaran Daring Dalam Perkuliahan Bahasa Indonesia Di Perguruan Tinggi." Journal Indonesian Language Education and Literature 3(1):53-65.

Mustakim. 2020. “Efektivitas Pembelajaran Daring Menggunakan Media Online Selama Pandemi Covid-19 Pada Mata Pelajaran Matematika the Effectiveness of E-Learning Using Online Media During the Covid-19 Pandemic in Mathematics." Al Asma: Journal of Islamic Education 2(1):1-12.
Mustika, Marleen. 2020. “'Efektivitas Pemanfaatan Aplikasi Whatsapp dalam Pengambilan Keputusan Redaksi' (Studi/ : Redaksional Harian Rakyat Maluku)." Badati 2(1):85-97.

P, Acero, K. Cabas, C. Caycedo, P. Figueroa, G.Patrick \&. M.Rudas., and kue tradisional khas Aceh. 2020. "Sistem Pembelajaran Daring Menggunakan Media Online Pada Era Covid-19." (September):92027.

Prajana, Andika. 2017. "Pemanfaatan Aplikasi Whatsapp Untuk Media Pembelajaran Dalam Lingkungan Uin Ar-Raniry Banda Aceh." Cyberspace: Jurnal Pendidikan Teknologi Informasi 1(2):122.

Rahartri. 2019. “'Whatsapp' Media Komunikasi Efektif Masa Kini (Studi Kasus Pada Layanan Jasa Informasi Ilmiah Di Kawasan Puspiptek)." Visi Pustaka 21(2):147-56.

Sadikin, Ali, and Afreni Hamidah. 2020. "Pembelajaran Daring Di Tengah Wabah Covid-19." Biodik 6(2):109-19.

Sartika. 2018. "Kegunaan Whatsapp Sebagai Media Informasi Dan Media Pembelajaran Pada Mahasiswa Ilmu Komunikasi STISIP Persada Bunda." Medium 6(2):15-26. 